\title{
Inhibition of Rat Mixed Lymphocyte Cultures by Suppressor Macrophages
}

\author{
J. Ronald Oehler,,${ }^{1,2,4}$ Ronald B. Herberman, ${ }^{1}$ Darkell A. Campbelt, Jr., ${ }^{1,2}$ \\ AND JULIE Y. DJEU ${ }^{3}$ \\ ${ }^{1}$ Laboratory of Immunodiagnosis, National Cancer Institute, Bethesda, Maryland 20014, \\ ${ }^{2}$ Department of General Surgery, University of Michigan Hospital, Ann Arbor, \\ Michigan 48104, and ${ }^{3}$ Department of Immunology, Litton Bionetics, Inc., \\ 5516 Nicholson Lane, Kensington, Maryland 20795
}

Received October 1, 1976

\begin{abstract}
Normal rat spleens contain suppressor cells which can inhibit proliferative and cytotoxic responses of lymphocytes to alloantigens in vitro. The suppressor cells are adherent, phagocytic, resistant to treatment with ATS and C, radioresistant, resistant to treatment with mitomycin $\mathrm{C}$, apparently absent from the thymus, and found in very high concentrations in peritoneal exudates. These characteristics indicate that the suppressor cell is a macrophages and not a $\mathrm{T}$ cell. When suppressor cells were removed from spleen cell suspensions, strong in vitro proliferative and cytotoxic responses to alloantigens could consistently be observed.
\end{abstract}

\section{INTRODUCTION}

In vitro lymphoproliferative responses have been difficult to demonstrate in the spleens of rats (1). Consistent demonstration of in vitro generation of high cytotoxic reactivity to alloantigens which is dependent on a proliferative response (2-4) required the use of lymph node cells as responders (5). In contrast, in mice, the spleen is routinely used as a source of effector cells for $\mathrm{MLC}-\mathrm{CML}^{5}$ reactions and thus the poor reactivity in the rat spleens has not been easily explained. Two main possibilities need to be considered: either the rat, unlike the mouse, does not have alloreactive cells in the spleen, suggesting a different functional T-cell distribution in closely related species, or the rat spleen contains suppressor cells which can inhiluit proliferative responses. A recent study of CML in rats has shown that their spleens do have cells capable of a proliferative and cytotoxic response to alloantigen, but these responses were demonstrable only after depletion of an adherent

* Address reprint requests to Dr. J. Ronald Oehler, Laboratory of Immunodiagnosis, National Cancer Institute, Building 8, Room 112, Bethesda, Maryland 20014.

${ }^{5}$ Abbreviations used in this paper: MLC, mixed lymphocyte culture; CML, cell-mediated lympholysis (in vitro generation of a cytotoxic response to alloantigen); GIA, growth inhibition assay; MLTI, mixed lymphocyte tumor interactions; ATS and $\mathrm{C}$, anti-T cell serum and complement; DSS, IIanks' balanced salt solution; PEC, peritoneal exuldite cells; W/Fu, Wistar Furth; BN, Brown Norway; 2-ME, 2-mercaptoethanol; FBS, fetal bovine serum; ${ }^{8} \mathrm{H}-\mathrm{TdR}$, tritiated thymidine; LNC, lymph node cell ; PBL, peripheral blood leukocyte; MMC, mitomycin $\mathrm{C}$. 
cell population from the responding cells prior to culture (6). The adherent cell population, however, was not characterized. Folch and Waksman ( 7 ) have presented data which they interpreted as demonstrating an adherent T-suppressor cell which can strongly inhibit MLC in rat spleens (7). From that work, it would appear that an adherent $T$-suppressor cell was responsible for the inability of unfractionated rat spleen cells to respond in MLC or to generate CML.

Our laboratory has done extensive testing to suppressor cell activity in both tumor and non-tumor systems (8-12) and has found adherent suppressor cells with the characteristics of macrophages and not $T$ cells. Recently, normal rat spleens, unlike normal mouse spleens, were found to have activity in the growth inhibition assay, which has been shown to measure cytostatic macrophage activity $(13,14)$. In addition, we found that cells active in the growth inhibition assay were also active in suppression of the in vitro secondary proliferative response to tumor-associated antigens (MLTI) (13). This appeared to be in contrast to the findings of Folch and Waksman, but since our findings were in a tumor system involving a secondary response and they had studied a primary response to alloantigen, it was possible the findings were not comparable. In order to compare our findings directly, we have developed an MLC-CML system in rats and have characterized the adherent suppressor cells in the normal rat spleen. Our data indicate that the suppressor cells in normal rat spleens which inhibit both MLC and CML are macrophages and not $\mathrm{T}$ cells. Possible reasons for these disparate findings are discussed.

\section{MATERIALS AND METHODS}

\section{Animals}

Eight- to 10-week-old male W/Fu (Ag-B2) rats usually served as donors for responding cells. Ex-breeder male and female $\mathrm{BN}$ (Ag-B3) rats usually served as donors of stimulating cells. All rats were obtained from Microbiological Associates, Inc., Walkersville, Md.

\section{Preparation of Lymphoid Cells}

Spleen, lymph node and thymus cell suspensions were prepared as previously described (15). Peripheral blood lymphocytes (PBL) were obtained by cardiac puncture. Ten milliliters of heparinized blood were diluted with $10 \mathrm{ml}$ of BSS and carefully layered over $10 \mathrm{ml}$ of Ficoll Hypaque (LSM, Litton Bionetics, Rockville, $\mathrm{Md}$.) at $22^{\circ} \mathrm{C}$. The gradicnt was then centrifuged at $250 \mathrm{~g}$ at $22^{\circ}$ for 30 min after which the cells layered at the interface of the Ficoll and BSS were carefully collected, washed and resuspended in complete medium (see below). This procedure resulted in a lymphoid population free of granulocytes and consisting of small lymphocytes and monocytes. Peritoneal exudate cells (PEC) were collected from the peritoneal cavity 4 days after injection of $20 \mathrm{ml}$ of light mineral oil i.p. Latex particle ingestion techniques consistently showed that $45-55$ percent of the cells obtained were phagocytic; the remainder appeared under light microscopy to be small lymphocytes.

\section{Cell Separation Procedures}

The medium used for all experiments and cell separation procedures was as follows: RPMI medium 1640 (Grand Island Biological Co., Grand Island, N. Y.) 
containing $25 \times 10^{-3} M$ HEPES solution (Microbiological $\Lambda$ ssociates, Inc., Bethesda, Md.), $5 \times 10^{-5} M 2$-mercaptoethanol (Schwarz-Mann Division, Becton, Dickinson \& Co., Orangeburg, N. Y.), 100 units of penicillin per ml, $100 \mu \mathrm{g}$ of streptomycin per $\mathrm{ml}$ and $60 \mu \mathrm{g} / \mathrm{ml}$ of gentamicin, $2 \mathrm{mM}$ of glutamine and $10 \%$ FBS (all reagents from Grand Island Biological Co.). This will be referred to as complete medium.

Carbonyl iron and magnet. Spleen cells $\left(1 \times 10^{8}\right)$ in $5 \mathrm{ml}$ of medium were combined with $200 \mathrm{mg}$ of carbonyl iron powder (GAF Corp., New York, N.Y.) and incubated for $1 \mathrm{hr}$ at $37^{\circ} \mathrm{C}$ in a shaking water bath. Following the incubation period, the cell suspension was diluted to $10 \mathrm{ml}$ and serially poured from test tube to test tube using a strong magnet to retain cells having phagocytized the iron powder at each step. A series of $6-8$ test tubes was used. This procedure resulted in a decrease from $8-10 \%$ to $1-2 \%$ in the proportion of normal spleen cells which could ingest latex particles.

Passage of spleen cells through a rayon column. Thirty-five milliliter syringes were disassembled, and the barrel was filled with three rayon cotton balls (Parke Davis Co., Detroit, Mich.). The assembly was then autoclaved and prepared for use as follows: A sterile stopcock was placed on the tip of the syringe and $50 \mathrm{ml}$ of BSS were rapidly passed through the column. Then $5-8 \times 10^{8}$ spleen cells in media were placed on the column and incubated at $37^{\circ} \mathrm{C}$ in a $5 \% \mathrm{CO}_{2}$ humid atmosphere. After 20 min incubation, the nonadherent cells were eluted with $50 \mathrm{ml}$ of warm $\left(37^{\circ} \mathrm{C}\right) \mathrm{BSS}$, centrifuged at $250 \mathrm{~g}$ for $10 \mathrm{~min}$, and resuspended in completc medium. Twenty to $30 \%$ of the cells werc recovered by this procedurc. Latex particle ingesting cells decreased from $8-10 \%$ of the normal spleen population to $1-2 \%$. This procedure had virtually no effect on the percentage of cells bearing surface immunoglobulin $(40-50 \%$ of normal spleen population as measured by membrane surface immunofluorescence with fluorescein-conjugated goat anti-rat immunoglobulin [Lot \#4020201, prepared for NCI by Huntington Research Center, Brooklandville, Md.l) The levels of cell-mediated cytotoxicity of immune W/Fu spleen cells against (C58NT) D, a syngeneic Gross virus-induced lymphoma, which is T-cell dependent $(16,17)$, were either unchanged or increased after column passage.

\section{Removal of $T$ Cells}

A burro anti-rat thymocyte antiserum (ATS) was used to specifically remove $\mathrm{T}$ cells. The methods for producing and absorbing this antiserum have been described (16). One-tenth milliliter of this antiserum (diluted $1: 5$ ) and $0.1 \mathrm{ml}$ of undiluted guinea pig serum as a source of complement were added to $0.1 \mathrm{ml}$ of $1 \times 10^{7}$ spleen cells, and the mixture was incubated at $37^{\circ} \mathrm{C}$ for $1 \mathrm{hr}$. The cells were then washed twice with $50 \mathrm{ml}$ of $\mathrm{BSS}$ and resuspended in complete medium as previously reported (16). This procedure consistently and completely abrogated the proliferative response of the spleen cells to PHA and the cytotoxicity of immune lymphocytes against (C58NT)D. The number of antibody-producing spleen cells from rats immunized against sheep red blood cells was not decreased. In addition, macrophages shown to be active in the GIA were not decreased (13). 


\section{Assays of Functional Activity}

Mixed lymphocyte culture (MLC) was done as follows: $1 \times 10^{\mathrm{s}}$ stimulating cells (usually BN spleen cells) were treated with $50 \mu \mathrm{g}$ of mitomycin $\mathrm{C}$ in $1 \mathrm{ml}$ of complete medium for $45 \mathrm{~min}$ and washed twice in BSS and resuspended in complete medium. Responding cells were placed in culture with mitomycin Ctreated stimulating cells in $0.2 \mathrm{ml}$ of medium in microtiter $\mathrm{U}$ plates (Cooke Engineering Co., Alexandria, Va.). Cell concentrations of both stimulating and responding cells were varied from $4 \times 10^{6}$ cells $/ \mathrm{ml}$ to $0.5 \times 10^{6}$ cells $/ \mathrm{ml}$ to obtain optimum conditions. Culture periods varied from $48 \mathrm{hr}$ to $120 \mathrm{hr}$. One microcurie of ${ }^{3} \mathrm{H}$-thymidine ( $\left[{ }^{3} \mathrm{H}\right.$-TdR] specific activity $6 \mathrm{Ci} / \mathrm{mmol}$; Schwarz-Mann, Orangeburg, N.Y.) was added to each well for the final $16 \mathrm{hr}$ of the incubation period, and the cultures were harvested and further processed as previonsly described (8). All cultures were carried out in triplicate. All standrad errors were less than $5 \%$ and are not included in the tables.

Suppressor cell activity was demonstrated as described previously (13). Briefly, various numbers of spleen cells from the populations being tested for suppression were added to a fixed concentration $\left(2 \times 10^{6}\right.$ cells $\left./ \mathrm{ml}\right)$ of responding cells. Prior to the assay, the cells being tested for suppressor activity were either treated with mitomycin $\mathrm{C}$ or $\mathrm{x}$-irradiated with $2500 \mathrm{R}$. MLC was then done as above.

\section{In Vitro Generation of Cytotoxic Lymphocytes}

MLC was carried out as described above except that instead of adding ${ }^{3} \mathrm{H}-\mathrm{T} d \mathrm{R}$ and harvesting $16 \mathrm{hr}$ later, the cells were gently resuspended in each well with a $0.1 \mathrm{ml}$ semiautomatic pipette (Schwarz-Mann, Orangeburg, N.Y.) and $2 \times 10^{3}$ $\mathrm{BN}$ lymphoma [a Kirsten virus induced lymphoma (18) most gencrously provided by Dr. Frank Fitch, Department of Pathology, University of Chicago, Chicago, I11.] target cells, labeled with ${ }^{51} \mathrm{Cr}$ were added to each well. The plates were then incubated on a rocking platform for $4 \mathrm{hr}$ at $37^{\circ} \mathrm{C}$ in a $5 \% \mathrm{CO}_{2}$ humidified atmosphere and then centrifuged at $500 \mathrm{~g}$ for $10 \mathrm{~min}$. One-tenth milliliter of the supernatant was then carefully withdrawn from each microwell and counted for $10 \mathrm{~min}$ in a Searle gamma counter. Microwells with $0.2 \mathrm{ml}$ of distilled water to which labeled target cells were added served as controls for total releasable ${ }^{51} \mathrm{Cr}$. Supernatants drawn from wells containing distilled water after the 4-hr incubation period contained $80-90 \%$ of the total ${ }^{51} \mathrm{Cr}$ incorporated into the target cells. Baseline release was measured from microwells containing either labeled target cells alone or mitomycin C-treated stimulating cells and target cells. Values obtained with either method were always within $1.0 \%$ of each other and were consistently between 5 and $10 \%$ of the distilled water controls.

Percent cytotoxicity was calculated as follows:

$\%$ cytotoxicity $=\frac{\mathrm{cpm} \text { in sup of test group }-\mathrm{cpm} \text { in sup of baseline control }}{\mathrm{cpm} \text { in sup of distilled water control }-\mathrm{cpm} \text { of background }} \times 100$.

\section{RESULTS}

\section{Comparison of MLC Reactivity of Various Lymphoid Populations}

To ensure optimal conditions when comparing various lymphoid populations for MLC reactivity, various concentrations of both stimulating and responding cells, 
from $5 \times 10^{5}$ to $4 \times 10^{6}$ cells per $\mathrm{ml}$, were mixed. $\mathrm{BN}$ stimulating cells were blocked with mitomycin $\mathrm{C}$ and never incorporated ${ }^{3} \mathrm{H}$-TdR greater than background levels when cultured alone. $\mathrm{W} / \mathrm{Fu}$ responding cells incorporated similar amounts of ${ }^{3} \mathrm{H}-\mathrm{TdR}$ whether cultured alone or with various concentrations of syngeneic cells treated with mitomycin C. In most experiments the responding cells were cultured alone as controls. Figure 1 shows the results of an experiment comparing MLC reactivity of lymph node cells (LNC), peripheral blood lymphocytes (PBL), and spleen cells to $\mathrm{BN}$ alloantigens. A responding cell concentration of $2 \times 10^{6}$ per $\mathrm{ml}$ was optimal to demonstrate a proliferative response although a broad dose response relationship was seen when the responding cell concentrations were varied. Stimulating cells also produced strong proliferative responses over a broad range of concentrations. For subsequent experiments, $5 \times 10^{5}$ cells per $\mathrm{ml}$ was used as the stimulating cell concentration because that concentration consistently elicited the best proliferative response. Figure 1 also shows the kinetics of the reactivity of the various populations. Peak reactivity of the PBL was seen at about Day 4. This was variable, however, with similar levels of reactivity frequently being demonstrated both on Days 4 and 5. LNC reactivity was frequently demonstrable by Day 3 but usually peaked on Day 4 and dropped off sharply by Day 5 . The responses of the spleen cells, on the other hand, usually peaked on Day 3, if any significant reactivity could be seen at all (Fig. 1c and d). The responses shown in Figure 1a, 1b, and $1 \mathrm{c}$ are from one experiment using the same pool of $\mathrm{BN}$ stimulating cells. Figure $1 \mathrm{~d}$ is included as a separate kinetic study of the MLC reactivity of rat spleens, again showing low MLC reactivity of the spleen cells. These data indicate that although $\mathrm{W} / \mathrm{Fu}$ rats responded well to $\mathrm{BN}$ alloantigen, as demonstrated by the MLC responses of LNC and PBL, spleen cells responded poorly or not at all.

\section{MLC Reactivity of Normal Spleen Cells after Depletion of Various Populations}

Using the conditions found to be optimal for MLC reactivity, responding spleen cells were depleted of adherent or phagocytic cells and then tested for their ability

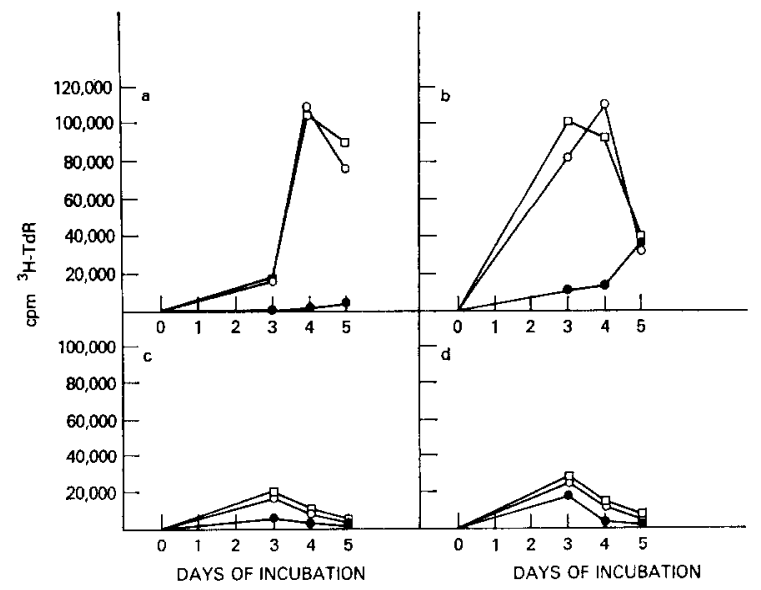

FIG. 1. Kinetic study of MLC reactivity in various lymphoid populations. (a) PBL, (b) LNC, (c) spleen cells, (d) spleen cells. $=\mathrm{cpm}$ of responding cells alone $\left(2 \times 10^{n}\right.$ cells $\left./ \mathrm{ml}\right)$. $\mathrm{O}=\mathrm{cpm}$ in MLC with $0.5 \times 10^{\circ} \mathrm{cells} / \mathrm{ml}$ as $\mathrm{BN}$ stimulating cell concentration. $\square=$ cprn in MLC with $1 \times 10^{\circ} \mathrm{cells} / \mathrm{ml}$ as $\mathrm{BN}$ stimulating cell concentration. 


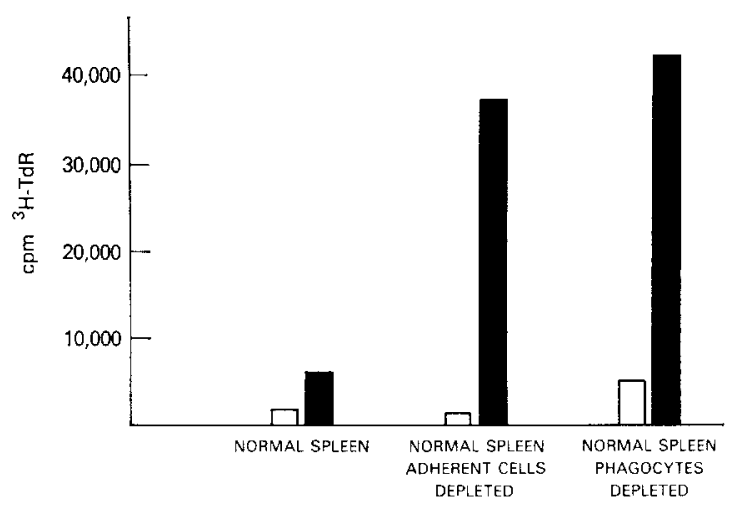

FIG. 2. Comparison of MLC reactivity before and after depletion of adherent (column passage) or phagocytic (treated with iron and magnet) cells. Open bars represent cpm of effector cells incubated alone. Closed bars represent cpm of effector cells stimulated with BN spleen cells treated with mitomycin $\mathrm{C}$.

to respond in the MLC. The results in Figure 2 show the MLC response was greatly improved after depletion of adherent or phagocytic cells. The results of this experiment indicate that rat spleens contain cells which can respond vigorously to BN alloantigens, thus ruling out the possibility that the decreased MLC reactivity observed with spleen cells was due to the absence of a highly reactive subpopulation of $\mathrm{T}$ cells. However, although surface immunofluorescence studies have shown the $\mathrm{T}$-cell/B-cell ratio to be relatively undisturbed after column passage or iron treatment, the possibility remained that the enhanced reactivity seen after

TABLE 1

Effect of Addition of Third Party Cells to MLC.

\begin{tabular}{|c|c|c|c|c|}
\hline \multirow[t]{2}{*}{ Stimulating cells } & \multicolumn{2}{|c|}{ Responding cells } & \multicolumn{2}{|c|}{ Third party cells added ${ }^{b}$} \\
\hline & $\begin{array}{l}\text { Normal spleen } \\
\text { unfractionated }\end{array}$ & $\begin{array}{l}\text { Normal spleen } \\
\text { column passage }\end{array}$ & + Normal spleen & $\begin{array}{l}\text { + Normal spleen } \\
\text { column passage }\end{array}$ \\
\hline \multicolumn{5}{|l|}{ Experiment 1} \\
\hline \multirow{3}{*}{$\begin{array}{l}\text { Media } \\
\text { BN spleen }\end{array}$} & $9,385^{a}$ & 2,277 & 6.034 & 2,073 \\
\hline & 24,126 & 39,837 & 18.679 & 36,625 \\
\hline & $\begin{array}{l}\text { Normal spleen } \\
\text { unfractionated }\end{array}$ & $\begin{array}{l}\text { Normal spleen } \\
\text { column passage }\end{array}$ & + Normal spleen & $\begin{array}{l}+ \text { Normal spleen } \\
\text { iron and magnet }\end{array}$ \\
\hline \multicolumn{5}{|l|}{ Experiment 2} \\
\hline Media & 1,675 & 1,210 & 3,025 & 6,010 \\
\hline \multirow[t]{2}{*}{ BN spleen } & 5,845 & 34,460 & 10,395 & 31,420 \\
\hline & $\begin{array}{l}\text { Normal spleen } \\
\text { unfractionated }\end{array}$ & $\begin{array}{l}\text { Normal spleen } \\
\text { column passage }\end{array}$ & + Normal spleen & $\begin{array}{c}+ \text { Normal spleen } \\
2500 \mathrm{R}\end{array}$ \\
\hline \multicolumn{5}{|l|}{ Experiment 3} \\
\hline Media & $5,5\rfloor 1$ & 722 & 1,878 & 1,953 \\
\hline \multirow[t]{2}{*}{$\mathrm{BN}$ spleen } & 11,706 & 37,550 & 14,914 & 11,031 \\
\hline & & & 1. Thymus & $\begin{array}{c}\text { + Normal spleen } \\
\text { ATS and C }\end{array}$ \\
\hline Media & & & 4,835 & 1,626 \\
\hline $\mathrm{BN}$ spleen & & & 33,570 & 3,754 \\
\hline
\end{tabular}

${ }^{4} \mathrm{C} m{ }^{3} \mathrm{H}-\mathrm{TdR}$

$b$ Third party cells were treated with mitomycin $\mathrm{C}$ unless otherwise noted and added in concentrations equal to that of the column-passaged responding cells. 
these purification procedures was the result of increasing the percentage of a reactive subpopulation of $\mathrm{T}$ cells rather than depleting s11ppressor cells.

\section{Addition of Various Populations of Cells as Third Parties to the MLC}

If normal spleen cells contained suppressor cells, addition of unfractionated cells as third parties to MLC with column-purified responder spleen cells should suppress the reactivity. To test this possibility, unfractionated spleen cclls were treated with mitomycin $\mathrm{C}$ or with $2500 \mathrm{R}$ x-irradiation to prevent a proliferative response and added as third parties into the MLC in concentrations equal to the responding cells. Table 1 shows the results of three representative experiments. In each experiment, the MLC reactivity of the unfractionated population was compared to that of the column-passaged population. In addition, some of the third party cells were pretreated to deplete various subpopulations. In experiment 1, addition of unfractionated spleen cells greatly reduced the MLC of the column-passaged cells. In contrast, addition of the same number of column-passaged cells did not significantly decrease the MLC of the column-passaged responders. This indicates that adherent suppressor cells are present in the spleen.

Experiment 2 shows that pretreatment of the third party spleen cells with iron and magnet to deplete phagocytes was also highly effective in removing suppressor cells. In experiment 3 , the suppressor cclls were shown to be resistant to $2500 \mathrm{R}$, absent from the thymus, and resistant to treatment with ATS plus complement. These experiments indicate that the rat spleen has cells capable of inhibiting a proliferative response to alloantigen and that the cells are resistant to mitomycin $\mathrm{C}$, $\mathrm{x}$-irradiation, and treatment with a specific heterologous $\mathrm{T}$-cell serum plus complement. In addition, they are adherent and phagocytic and not found in the thymus.

TABLE 2

Kinetics of In Vitro Generation of Cytotoxicity with Lnfractionated Spleen Cells

\begin{tabular}{lrrr}
\hline Stimulating cells & \multicolumn{3}{c}{ Days in culture } \\
\cline { 2 - 4 } & Day 3 & Day 4 & Day 5 \\
\hline Experiment 1 & & & \\
Media & $2.3^{a}$ & 1.6 & -0.3 \\
BN spleen (0.5) & 8.9 & 14.4 & 8.4 \\
Experiment 2 & & & \\
Media & 0.7 & 1.2 & 0.4 \\
BN spleen (0.5) & 10.4 & 24.8 & 7.7 \\
Experiment 3 & & & \\
Media & 3.4 & 1.5 & \\
BN spleen (0.5) & 12.7 & 38.7 & \\
Experiment 4 & & & \\
Media & & & \\
BN spleen (0.5) & 16.5 & 34.4 & 15.5 \\
BN spleen (1) & 10.9 & 23.9 & 23.3 \\
\hline
\end{tabular}

a Percent cytotoxicity.

${ }^{b}$ Cells $/ \mathrm{ml} \times 10^{-6}$. 
TABLE 3

Comparison of CML Generated with Various Populations of Responding Cells After 4 Days of Culture

\begin{tabular}{|c|c|c|c|}
\hline \multirow{2}{*}{$\begin{array}{l}\text { Stimulating cell } \\
\text { concentration }\end{array}$} & \multicolumn{3}{|c|}{ Responding populations } \\
\hline & $\begin{array}{l}\text { Unfractionated } \\
\text { spleen }\end{array}$ & $\begin{array}{l}\text { Spleen after } \\
\text { column passage }\end{array}$ & $\begin{array}{c}\text { Spleen after } \\
\text { iron and magnet }\end{array}$ \\
\hline \multicolumn{4}{|l|}{ Experiment 1} \\
\hline $\begin{array}{l}\text { Media } \\
\text { BN spleen }(0.5)^{b}\end{array}$ & $\begin{array}{l}-1.4^{a} \\
11.1\end{array}$ & $\begin{array}{r}2.0 \\
64.0\end{array}$ & \\
\hline \multicolumn{4}{|l|}{ Experiment 2} \\
\hline $\begin{array}{l}\text { Media } \\
\text { BN spleen }(0.5) \\
\text { BN spleen (1) }\end{array}$ & $\begin{array}{l}2.4 \\
3.6 \\
3.3\end{array}$ & $\begin{array}{r}2.3 \\
34.1 \\
46.6\end{array}$ & \\
\hline \multicolumn{4}{|l|}{ Experiment 3} \\
\hline $\begin{array}{l}\text { Media } \\
\text { BN spleen }(0.5) \\
\text { BN spleen (1) }\end{array}$ & $\begin{array}{r}0.5 \\
34.4 \\
23.0\end{array}$ & & $\begin{array}{r}1.5 \\
54.9 \\
55.7\end{array}$ \\
\hline BN spleen (1) & $\begin{array}{l}\text { Unfractionated } \\
\text { lymph node cells }\end{array}$ & & $\begin{array}{l}\text { Lymph node cells } \\
\text { after iron and } \\
\text { magnet }\end{array}$ \\
\hline \multicolumn{4}{|l|}{ Experiment 4} \\
\hline $\begin{array}{l}\text { Media } \\
\text { BN spleen (0.5) }\end{array}$ & $\begin{array}{r}-0.4 \\
63.3\end{array}$ & & $\begin{array}{r}0.6 \\
66.8\end{array}$ \\
\hline
\end{tabular}

${ }^{a}$ Percent cytotoxicity.

${ }^{b}$ Cells $/ \mathrm{nll} \times 10^{-6}$.

In Vitro Generation of Cytotoxic Effector Cells to Alloantigen Using Rat Spleen Cells as Responders

The ability of spleen cells to become cytotoxic after MLC was also examined. Pilot kinetic experiments with unfractionated spleen cells showed the highest cytotoxicity was on the fourth day of culture. Various stimulator/responder cell ratios were tested and the concentrations which were best for the proliferative response were most consistently optimal for the development of cytotoxic effector cells. After 4 days of culture, $2 \times 10^{5}$ viable cells remained in each microwell (about $50 \%$ of the original number). Addition of $2 \times 10^{3}$ labeled target cells, for an attacker/target cell ratio of 100 to 1 , consistently resulted in the highest percentage of target cell lysis. Under these conditions, several experiments were performed to more carefully determine the kinetics of the CML of unfractionated spleen cells (Table 2). As in the pilot experiments, peak cytotoxicity consistently occurred on Day 4.

Depletion of the Adherent and Phagocytic Cells from the Responding Cells in the $C M L$

In experiments similar to those described for measuring proliferation, the responding spleen cells were placed through a rayon column to remove adherent cells 
or treated with iron and magnet to remove the phagocytes. Table 3 summarizes the results of several experiments. The levels of cytotoxicity generated with unfractionated spleen cells varied considerably among experiments, from undetectable responses to moderately high levels. In all cases, however, significant increases in the cytotoxic responses generated were observed after depletion of adherent or phagocytic cells. LNC became highly cytotoxic even without treatment and the cytotoxicity was not significantly improved by depletion of phagocytes.

\section{Addition of Various Lymphoid Populations to the CML as Third Parties to Characterize the Suppressor Cells}

Lymphoid cells from various sources were either $\mathrm{x}$-irradiated or treated with mitomycin $\mathrm{C}$ to prevent a proliferative response and were added in concentrations equal to that of the responding cells as third parties (Table 4). Experiment 1 shows again the enhanced cytotoxic response of cells depleted of adherent cells. This

TABLE 4

Effect of Addition of Third Party Cells on In Vitro Generation of Cytotoxicity

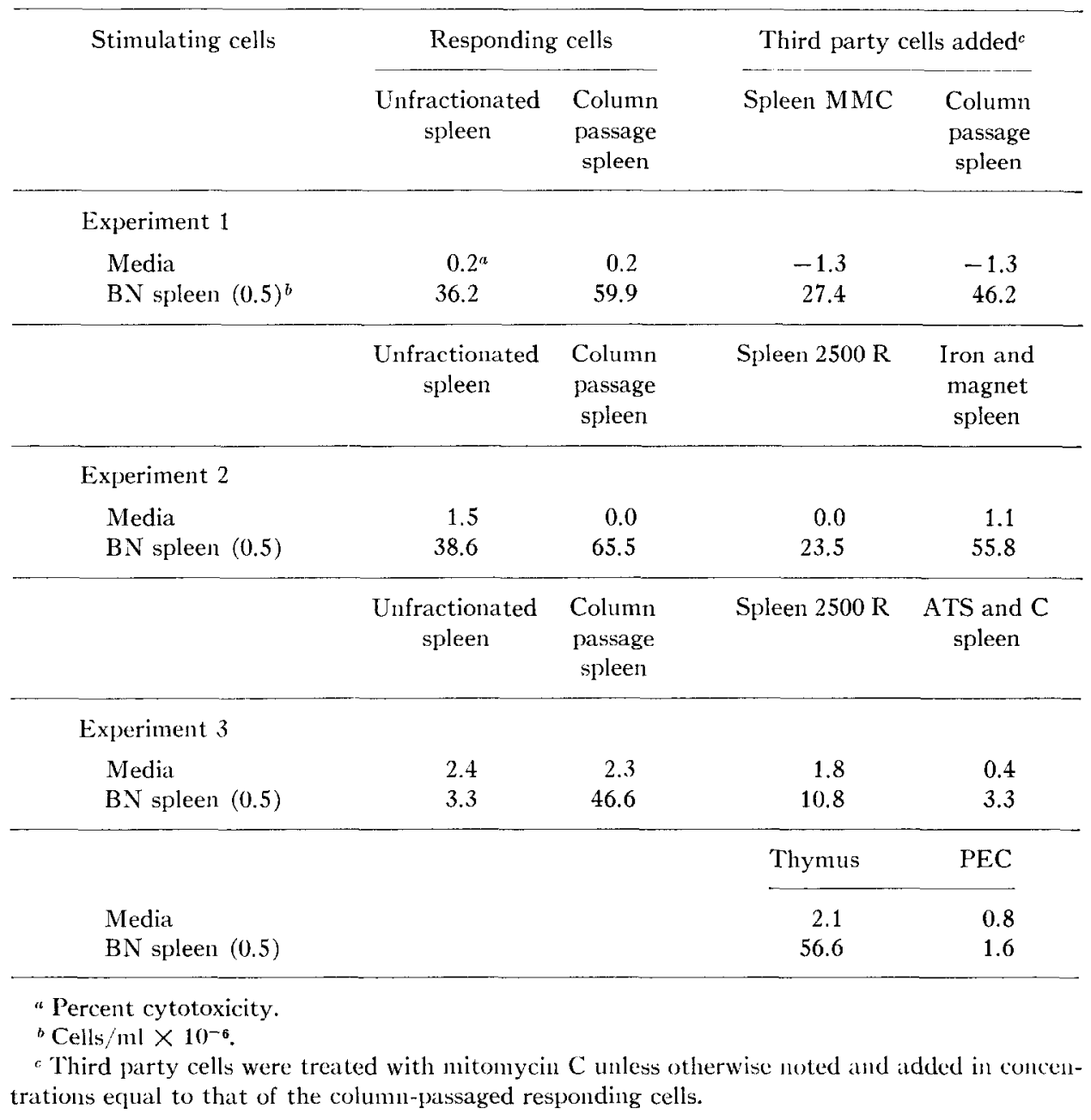


TABLE 5

Addition of Various Concentrations of Third Party Cells into CML Cultures With Column-Passaged Spleen Cells as Responders

\begin{tabular}{|c|c|c|c|c|c|c|c|c|}
\hline \multirow[t]{2}{*}{ Stimulating cells } & \multirow{2}{*}{$\begin{array}{l}\text { Source of third } \\
\text { party cells }\end{array}$} & \multicolumn{7}{|c|}{ Concentration of third party cells $\times 10^{-6} / \mathrm{ml}$ addert } \\
\hline & & 0 & 0.12 & 0.25 & 0.5 & 1.0 & 2.0 & 4.0 \\
\hline \multicolumn{9}{|l|}{ Experiment 1} \\
\hline Media & $\begin{array}{l}\text { Unfractionated } \\
\text { spleen }\end{array}$ & $2,3^{a}$ & & & & 1.4 & 1.8 & 1.6 \\
\hline BN spleen $(0.5)^{b}$ & & 46.6 & & & & 28.5 & 10.8 & 3.3 \\
\hline Media & Thymus & & & & & 3.4 & 2.1 & 3.6 \\
\hline BN spleen & & & & & & 46.3 & 56.6 & 48.2 \\
\hline Media & PEC & & 1.0 & 0.9 & 0.6 & 0.1 & 0.8 & \\
\hline BN spleen $(0.5)$ & & & 9.6 & 4.9 & 2.9 & 1.2 & 1.6 & \\
\hline \multicolumn{9}{|l|}{ Experiment 2} \\
\hline Media & $\begin{array}{l}\text { Unfractionated } \\
\text { spleen }\end{array}$ & -0.2 & & & 0.3 & -0.2 & -0.4 & 0.2 \\
\hline $\mathrm{BN}$ spleen $(0.5)$ & & 46.7 & & & 34.9 & 33.7 & 17.2 & 0.7 \\
\hline Media & Thymus & & & & & -0.8 & -0.1 & 0.7 \\
\hline $\mathrm{BN}$ spleen $(0.5)$ & & & & & & 38.6 & 37.5 & 40.7 \\
\hline Media & $\mathrm{PEC}$ & & -0.7 & 0.1 & -1.5 & -0.2 & 1.0 & 0.9 \\
\hline BN spleen $(0.5)$ & & & 18.7 & 3.5 & 8.6 & 0.9 & 0.6 & 1.5 \\
\hline
\end{tabular}

a Percent cytotoxicity.

${ }^{b} \mathrm{Cells} / \mathrm{ml} \times 10^{-6}$.

increased response was largely abrogated by addition of mitomycin C-treated unfractionated spleen cells to the cultures. In contrast, pretreatment of the third party cells with rayon column passage largely abrogated the suppressive effect. In experiment 2, addition of irradiated cells instead of cclls treated with mitomycin $\mathrm{C}$ demonstrated that the suppressive effect is radioresistant. In addition, pretreatment of the spleen cells with iron and magnet to deplete the phagocytic cells largely abrogated the suppressive effect of the unfractionated population. Experiment 3 shows that cells treated with ATS plus complement were even more suppressive than the unfractionated controls and this has heen a consistent finding. Addition of thymocytes into the CML cultures frequently stimulated the generation of cytotoxicity as shown in this experiment. In contrast, addition of light mineral oilinduced PECs always completely abrogated the cytotoxic response. Table 5 illustrates the relative suppressor activities of unfractionated spleen cells compared to thymus and PEC. In these experiments, column-passaged responding spleen cells were combined with various concentrations of the third party cells and the cytotoxicity generated measured on the fourth day of culture. In both experiments a concentration of spleen cells 16 times the concentration of PECs was requircd to give similar amounts of suppression. At no concentration tested did the addition of thymocytes suppress the cytotoxic response as much as the smallest dose of PECs.

\section{DISCUSSION}

The results of the present study provide an explanation for difficulties previously observed in generating a proliferative or cytotoxic response to alloantigens in vitro 
using rat spleens as responding cells $(1,6)$. We have found that the poor proliferative and cytotoxic responses observed are due to the activity of suppressor cells present normally in rat spleens and not to the lack of cells capable of responding. Experiments in which adherent or phagocytic cells were depleted from the responding cells showed greatly augmented MLC and CML activity. This suggested that the suppressor cells were phagocytic and adherent. This was supported by the finding that, although the addition of unfractionated cells into MLCs as third parties strongly suppressed both the proliferative and cytotoxic responses, spleen cells depleted of adherent or phagocytic cells had no such effect. Pretreatment of the cells with ATS and C never dccreased the suppressor effect and usually enriched for it. Thymocytes contained very little if any suppressor activity. In contrast, PECs consistently were very highly suppressive. In addition, the suppressor cell did not require proliferation to be effective as demonstrated by all the experiments in which the third party cells were either treated with mitomycin $\mathrm{C}$ or $\mathrm{x}$ irradiation. These data indicate the suppressor cells are probably macrophages. This is consistent with previous reports from our laboratory. Tumor-bearing mice (8) and rats (9) and mice injected with Corynebacterium parvum (19) have been shown to have a population of splenic macrophages which can inhibit proliferative responses to mitogens and tumor-associated antigens and also the in vitro generation of a secondary cytotoxic response to tumor-associated antigens. In addition, we have recently shown that normal rat spleens have suppressor macrophages which can inhibit secondary proliferative responses to tumor-associated antigens (13). Fernbach et al. (12) have shown that macrophages in PECs can inhibit MLC and CML in the mouse. The present study extends these observations to include the rat.

Spleen cells are routinely used in in vitro assays of cellular immunity in mice. From this study, it is apparent that unfractionated rat spleen cells may give suboptimal responses in in vitro assays. Whether suppressor macrophages are only present in normal rat spleens and not in normal mouse spleens, or whether the suppressor activity in normal mouse spleens is just too low to be detected in the usual in vitro assays is unclear. However, results of the growth inhibition assay [which reflects antiproliferative effects of macrophages in mice (14) and rats (13)] suggest that suppressor macrophage activity may exist in normal mouse spleens also but to a far lesser degree (14). Thus, it is likely that either rat splenic macrophages are more suppressive than mouse splenic macrophages or that rat lymphocytes are more sensitive to the suppressor effects. It is possible that rats are naturally exposed to more antigenic stimuli with resulting increased baseline levels of macrophage activation, but against this is the finding that germ-free rat spleens were just as inhibitory in the GIA as spleen cells of conventionally bred rats (Oehler and Herberman, unpublished observations).

Folch and Waksman (7) have previously described suppressor cell activity in the spleens of normal rats, which could inhibit MLC responses. They characterized the suppressor cell as adherent and sensitive to pretreatment with cycloheximide and resistant to pretreatment with mitomycin $C$. However, since they have found suppressor cell activity to be largely abrogated by adult thymectomy, irradiation, and bone marrow reconstitution, they have concluded that it is a $\mathrm{T}$ cell.

Our data would stuport the characteristics they described for the suppressor cell, i.e., that it is adherent and does not require proliferation to be effective. The 
main difference in our conclusions stems from the interpretation of the in vivo aspect of their studies, which indicated that $B$ rats have little or no suppressor activity. A reasonable explanation for the disparate findings would be that rat splenic macrophages may require a certain level of T-cell activity in zivo in order to acquire or maintain their suppressor activity. In rats without in vivo T-cell influence, splenic macrophages may become less activated or may migrate from the spleen. There is abundant evidence that, for some functions, $\mathrm{T}$ cells are required for activation of macrophages (20-22). We are currently performing experiments to directly determine whether the activation of splenic suppressor macrophages is T cell dependent.

Of central importance is the in vivo significance of these findings. In the past few years, much attention has been directed toward regulation of the immune response and numerous reports have implicated $\mathrm{T}$ cells as the primary regulatory cell. Depending on the conditions present, $T$ cells have been shown to either help or suppress B-cell responses to antigen (23). Similarly, $\mathrm{T}$ cells have been reported to suppress or enhance the responses of other T cells $(4,24-29)$. The present study shows that macrophage type non-T cells found in normal rat spleens can suppress $\mathrm{T}$-cell responses and therefore may also be involved in the regulation of the immune response. In addition, it is possible that in some studies in which suppressor $T$ cells have been described, as in the suppressor phenomenon reported by Folch and Waksman $(7)$, the suppressor cells may in fact be $T$ cell-dependent suppressor macrophages.

\section{ACKNOWLEDGMENTS}

The authors wish to express grateful acknowledgment to Mr. Leroy Lindsey, Mrs. Hilda Porter, and Mr. John Hoffman for competent technical assistance and conscientious maintenance of the animal colony.

\section{REFERENCES}

1. Wilson, D. B., J. Exp. Med. 126, 625, 1967.

2. Cantor, H., and Jandinski, J., J. Ext. Med. 140, 1712, 1975.

3. Nedrud, J., Touton, M., and Clark, W. R., J. Exp. Med. 142, 960, 1975.

4. Peavy, D. L., and Pierce, C. W., J. Immunol. 115, 1521, 1975.

5. Bruce, J., Goldstein, P., and Mitchison, N. A., Transplantation 20, 88, 1975.

6. Bernstein, I. D., Wright, P. W., and Cohen, E., Transplantation 21, 173, 1975.

7. Folch, H., and Waksman, B., I. Immunol. 113, 140, 1974.

8. Kirchner, H., Muchmore, A. V., Chused, T. M., IIolden, H. T., and Herberman, R. B., J. Immunol. 114, 206, 1975.

9. Glaser, M., Kirchner, H., and Herberman, R. B., Int. J. Cancer, 16, 384, 1975.

10. Glaser, M., Kirchner, H., Holden, H. T., and Herberman, R. B., J. Natl. Cancer Inst., in press.

11. Kirchner, H., Chused, T. M., Herberman, R. B., Holden, H. T., and Lavrin, D. H., J. Exp. Med. 139, 1473, 1974.

12. Fernbach, B. R., Kirchner, H., and Herberman, R. B., Cell. Immunol. 22, 399, 1976.

13. Oehler, J. R., Campbell, D. A., Jr., and Herberman, R. B., Cell. Immunol. 28, 355-370.

14. Kirchner, H., Holden, H. T., and Herberman, R. B., J. Natl. Cancer Inst. 55, 971, 1975.

15. Ortiz de Landazuri, M., and Herberman, R. B., J. Natl. Cancer Inst. 49, 147, 1972.

16. Djeu, J. Y., Glaser, M., Kirchner, H., Huang, K. Y., and Herberman, R. B., Ccll. Immunol. 12, 164, 1974.

17. Nunn, M. E., Djeu, J. Y., Glaser, M., Lavrin, D. H., and Herberman, R. B., J. Natl. Cancer Inst. 56, 393, 1976.

18. Kirsten, W. H., and Mayer, L. A., J. Natl. Cancor Inst. 43, 735, 1969. 
19. Kirchner, H., Glaser, M., and Herberman, R. B., Nature 257, 396, 1975.

20. Sheagren, J. N., Simon, H. B., Tuazon, C. U., and Mehrotra, P. P., In "Mononuclear Phagocytes in Immunity, Infection, and Pathology" (R. van Furth, Ed.), p. 653. Blackwell Scientific Publications, 1975.

21. Pfizenmaier, K., Trostmann, H., Rollinghoff, M., and Wagner, H., Immunology 29, 967 , 1975.

22. Lohmann-Matthes, M. L., and Fischer, H., Transplant. Rev. 17, 150, 1973.

23. Katz, D. H., and Benacerraf, B., Adv. Immunol. 15, 1, 1972.

24. Takei, F., Levy, J. G., and Kilburn, D. G., J. Immunol. 116, 288, 1976.

25. Whisler, R. L., and Stobo, J. D., J. Exp. Med. 144, 398, 1976.

26. Hirano, T., and Nordin, A. A., J. Immunol. 116, 1115, 1976.

27. Rich, S. S., and Rich, R. R., J. Exp. Mcd. 140, 1588, 1974.

28. Cohen, L., and Howe, M. L., Proc. Natl. Acad. Sci. U.S.A. 70, 2707, 1973.

29. Cantor, H., and Boyse, E. A., J. Exp. Med. 141, 1390, 1975. 